\title{
Front Matter: Volume 11012
}

, "Front Matter: Volume 11012," Proc. SPIE 11012, Detection and Sensing of Mines, Explosive Objects, and Obscured Targets XXIV, 1101201 (18 June 2019); doi: $10.1117 / 12.2536812$

SPIE Event: SPIE Defense + Commercial Sensing, 2019, Baltimore, MD, United SPIE. States 


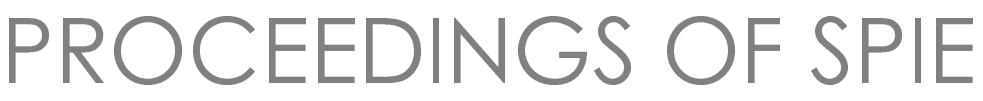

\section{Detection and Sensing of Mines, Explosive Objects, and Obscured Targets XXIV}

Steven S. Bishop

Jason C. Isaacs

Editors

15-17 April 2019

Baltimore, Maryland, United States

Sponsored and Published by

SPIE 
The papers in this volume were part of the technical conference cited on the cover and title page. Papers were selected and subject to review by the editors and conference program committee. Some conference presentations may not be available for publication. Additional papers and presentation recordings may be available online in the SPIE Digital Library at SPIEDigitalLibrary.org.

The papers reflect the work and thoughts of the authors and are published herein as submitted. The publisher is not responsible for the validity of the information or for any outcomes resulting from reliance thereon.

Please use the following format to cite material from these proceedings:

Author(s), "Title of Paper," in Detection and Sensing of Mines, Explosive Objects, and Obscured Targets XXIV, edited by Steven S. Bishop, Jason C. Isaacs, Proceedings of SPIE Vol. 11012 (SPIE, Bellingham, WA, 2019) Seven-digit Article CID Number.

ISSN: 0277-786X

ISSN: 1996-756X (electronic)

ISBN: 9781510626898

ISBN: 9781510626904 (electronic)

Published by

SPIE

P.O. Box 10, Bellingham, Washington 98227-0010 USA

Telephone +1 3606763290 (Pacific Time) · Fax +1 3606471445

SPIE.org

Copyright @ 2019, Society of Photo-Optical Instrumentation Engineers.

Copying of material in this book for internal or personal use, or for the internal or personal use of specific clients, beyond the fair use provisions granted by the U.S. Copyright Law is authorized by SPIE subject to payment of copying fees. The Transactional Reporting Service base fee for this volume is $\$ 18.00$ per article (or portion thereof), which should be paid directly to the Copyright Clearance Center (CCC), 222 Rosewood Drive, Danvers, MA 01923. Payment may also be made electronically through CCC Online at copyright.com. Other copying for republication, resale, advertising or promotion, or any form of systematic or multiple reproduction of any material in this book is prohibited except with permission in writing from the publisher. The CCC fee code is $0277-$ $786 \times / 19 / \$ 18.00$.

Printed in the United States of America by Curran Associates, Inc., under license from SPIE.

Publication of record for individual papers is online in the SPIE Digital Library.

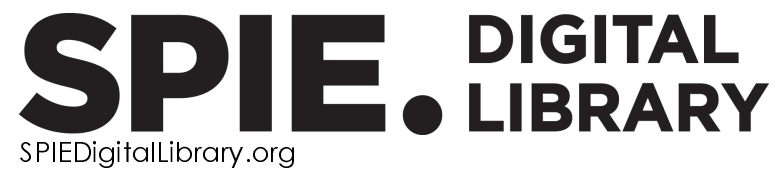

Paper Numbering: Proceedings of SPIE follow an e-First publication model. A unique citation identifier (CID) number is assigned to each article at the time of publication. Utilization of CIDs allows articles to be fully citable as soon as they are published online, and connects the same identifier to all online and print versions of the publication. SPIE uses a seven-digit CID article numbering system structured as follows:

- The first five digits correspond to the SPIE volume number.

- The last two digits indicate publication order within the volume using a Base 36 numbering system employing both numerals and letters. These two-number sets start with $00,01,02,03,04$, 05, 06, 07, 08, 09, OA, OB ... 0Z, followed by 10-1Z, 20-2Z, etc. The CID Number appears on each page of the manuscript. 


\title{
Contents
}

\author{
vii Authors \\ ix Conference Committee
}

\section{SESSION 1 APPLIED MACHINE LEARNING}

1101202 Machine learning based automatic target recognition algorithm applicable to ground penetrating radar data (Invited Paper) [1 1012-1]

1101205 Deep convolutional neural network target classification for underwater synthetic aperture sonar imagery [1 $1012-5]$

1101206 Reliable training of convolutional neural networks for GPR-based buried threat detection using the Adam optimizer and batch normalization [ $1101012-6]$

\section{SESSION 2 APPLIED FEATURE EXTRACTION I}

$1101207 \quad$ Identification of buried objects based on peak scatter modelling of GPR A-scan signals [11012-7]

1101208 Comparing target information in voxel and pixel ultra-wideband radar images [11012-8]

1101209 On the use of multiresolution analysis for subsurface object detection using deep ground penetrating radar [ $1101012-9]$

$110120 \mathrm{~A} \quad$ Evaluation of image features for discriminating targets from false positives in synthetic aperture sonar imagery [1 1012-10]

\section{SESSION $3 \quad$ APPLIED FEATURE EXTRACTION II}

$11012 \mathrm{OB} \quad$ Feature extraction for predicting the probability of detecting buried explosive objects using GPR data [1 1012-11]

$110120 \mathrm{C}$ A comparative analysis of the SVM and K-NN to detect buried explosive objects using edge histogram features from GPR data [1 1012-12]

11012 OF An exploration of gradient-based features for buried threat detection using a handheld ground penetrating radar [ $1101012-15]$ 


\section{SESSION $4 \quad$ APPLIED FEATURE EXTRACTION III}

$110120 \mathrm{H}$ How transferable are downward-looking and handheld ground penetrating radar data? Experiments in the context of buried threat detection [1 1012-16]

SESSION 5 HYDROGEOLOGICAL EFFECTS

$1101201 \quad$ Analysis of the effect of salt water on time domain electromagnetic induction sensing of submerged metallic objects [1 1012-18]

$110120 \mathrm{~J} \quad H y d r o-e l e c t r o m a g n e t i c$ properties in ground-penetrating radar field target detection studies [1 1012-19]

\section{SESSION $6 \quad$ UAS APPLICATIONS}

11012 OK Buried object imaging using a small UAS-based GPR [1 $1012-20]$

$110120 \mathrm{~N} \quad$ Investigation of initialization strategies for the Multiple Instance Adaptive Cosine Estimator [1 $11012-3]$

\section{SESSION 7 CLASSIFICATION SCHEMES I}

1101200 A portable discrete frequency NQR explosives detection system [1 1012-23]

11012 OP Multi-phase performance evaluation for modern minehunting systems [1 1012-24]

$110120 Q \quad$ High-frequency electromagnetic induction (HFEMI) data from carbon rods, wires, and improvised explosive device constituent parts [1 1012-25]

11012 OR Classification using low-rank features from an electromagnetic induction sensor [1 $1012-26]$

11012 OT Comparison of possibilistic fuzzy local information C-means and possibilistic K-nearest neighbors for synthetic aperture sonar image segmentation [1 1012-28]

\section{SESSION 8 CLASSIFICATION SCHEMES II}

11012 OU Comparison of hand-held WEMI target detection algorithms [1 $1012-29]$

$110120 \mathrm{~V} \quad$ Scalable high-resolution algorithms for landmine imaging problem [1 1012-30]

11012 OW Doppler-vibrometer landmine-detection system operated from a moving vehicle [11012-31] 
$110120 \mathrm{X}$ Investigating time domain EMI signals diffusion in a conducting environment for UXO detection and classification [1 1012-32]

\section{SESSION 9 SENSING MELANGE I}

$110120 \mathrm{Y}$ Transfer and multitask learning using convolutional neural networks for buried wire detection from ground penetrating radar data [1 1012-46]

$110120 Z$ Combined use of remote sensing data and geographic information system techniques for defecting underground structures for defense and security applications in Cyprus [1 1012-37]

1101210 Counter-mine augmented reality training system (CMARTS) [1 1012-38]

1101211 Dual-band discrimination and imaging of plastic objects [1 1012-39]

$1101212 \quad$ New possibilities of post-blast residues analysis in forensic science [1 1012-40]

1101213 In-vehicle illumination-invariant change detection based on intrinsic images and differences of Gaussians [1 1 $1012-41$ ]

\section{SESSION 10 SENSING MELANGE II}

$1101214 \quad$ Enhanced metal detection using Halbach arrays [1 1012-42]

1101215 Path reconstruction from nontraditional sensor information using subgraph isomorphism algorithms [1 $101012-36]$

\section{SESSION 11 SENSING MELANGE III}

1101216 Dual sensor ALIS evaluation test in Cambodia [1 1012-33]

1101217 Quadratic liffing inversion applied to buried object radar imaging [1 1012-34]

1101218 Exploiting polarization of very low frequency scattered fields to localize objects [1 1012-35]

\section{POSTER SESSION}

1101219 Multiparametric full waveform inversion of 2D ground penetrating radar data using multiple GPUs [1 $11012-43]$ 
$110121 \mathrm{~A} \quad$ Detection of the buried landmine/projectile using LS-band FLGPR vehicle [1 1012-44]

$110121 \mathrm{C}$ Orbital angular momentum assisted ground penetrating radar [1 1012-47]

Proc. of SPIE Vol. 11012 1101201-6

Downloaded From: https://www.spiedigitallibrary.org/conference-proceedings-of-spie on 26 Apr 2023 Terms of Use: https://www.spiedigitallibrary.org/terms-of-use 


\section{Authors}

Numbers in the index correspond to the last two digits of the seven-digit citation identifier (CID) article numbering system used in Proceedings of SPIE. The first five digits reflect the volume number. Base 36 numbering is employed for the last two digits and indicates the order of articles within the volume. Numbers start with 00, 01, 02, 03, 04, 05, 06, 07, 08, 09, OA, OB...0Z, followed by 10-12, 20-2Z, etc.

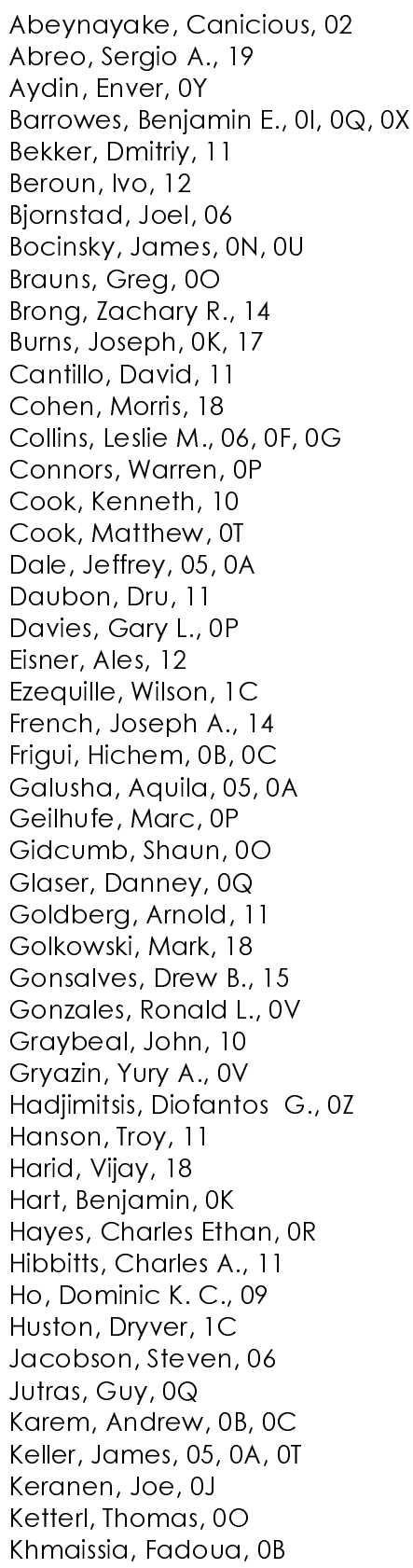

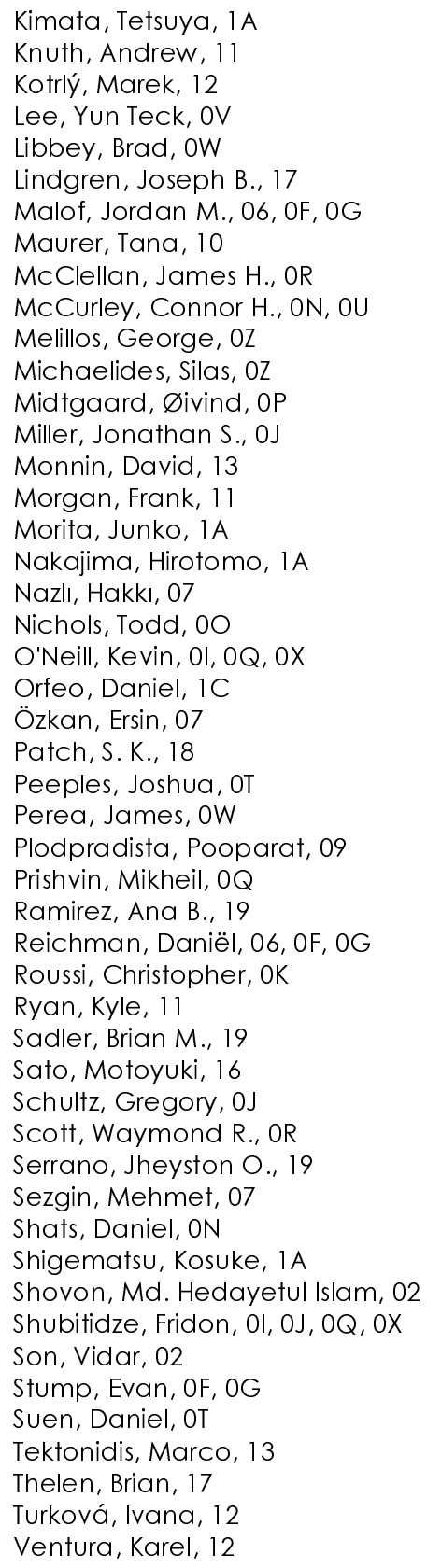


Warakagoda, Narada, OP

Wilder, Shawn M., 08

Wilson, Joseph N., 15

Wilson, Matthew S., 08

Winker, Daniel, 14

Xia, Tian, 1C

Xique, Ismael, OK, 17

Yokohama, Hiroshi, 02

Yoldemir, Burak, 07

Yüksel Erdem, Seniha Esen, OY

Zare, Alina, 05, 0A, 0N, 0T, OU 


\section{Conference Committee}

Symposium Chairs

Jay Kumler, JENOPTIK Optical Systems, LLC (United States)

Ruth Moser, Air Force Research Laboratory (United States)

Symposium Co-chair

John Pellegrino, Electro-Optical Systems Laboratory, Georgia Institute of Technology (United States)

Conference Chairs

Steven S. Bishop, U.S. Army Night Vision \& Electronic Sensors

Directorate (United States)

Jason C. Isaacs, Naval Surface Warfare Center Panama City Divison (United States)

Conference Program Committee

Canicious G. Abeynayake, Defence Science and Technology Group (Australia)

Derek T. Anderson, Mississippi State University (United States)

Benjamin E. Barrowes, U.S. Army Engineer Research and Development Center (United States)

Leslie M. Collins, Duke University (United States)

Anthony A. Faust, Defence Research and Development Canada, Suffield (Canada)

Tesfaye G-Michael, Naval Surface Warfare Center Panama City Divison (United States)

Pete Howard, U.S. Army CERDEC NVESD (United States)

James M. Keller, University of Missouri-Columbia (United States)

Aaron LaPointe, U.S. Army Night Vision \& Electronic Sensors

Directorate (United States)

Henric Östmark, Swedish Defence Research Agency (Sweden)

Motoyuki Sato, Tohoku University (Japan)

Waymond R. Scott Jr., Georgia Institute of Technology (United States)

Alina Zare, University of Florida (United States)

Session Chairs

$1 \quad$ Applied Machine Learning

Ken E. Yasuda, U.S. Army RDECOM CERDEC NVESD (United States)) 
Applied Feature Extraction I

Ken E. Yasuda, U.S. Army RDECOM CERDEC NVESD (United States)

Mihail Popescu, University of Missouri (United States)

3 Applied Feature Extraction II

Bradley W. Libbey, U.S. Army Night Vision \& Electronic Sensors Directorate (United States)

Canicious G. Abeynayake, Defence Science and Technology Group (Australia)

4 Applied Feature Extraction III

Tesfaye G-Michael, Naval Surface Warfare Center Panama City Divison (United States)

5 Hydrogeological Effects

Bradley W. Libbey, U.S. Army Night Vision \& Electronic Sensors Directorate (United States)

Michael Scholl, U.S. Army Night Vision \& Electronic Sensors Directorate (United States)

6 UAS Applications

Peter D. Howard, U.S. Army Night Vision \& Electronic Sensors Directorate (United States)

Alina Zare, University of Florida (United States)

7 Classification Schemes I

Jason C. Isaacs, Naval Surface Warfare Center Panama City Div. (United States)

Anthony A. Faust, Defence Research and Development Canada, Suffield (Canada)

8 Classification Schemes II

Aaron LaPointe, U.S. Army Night Vision \& Electronic Sensors Directorate (United States)

Waymond R. Scott Jr., Georgia Institute of Technology (United States)

9 Sensing Melange I

Steven S. Bishop, U.S. Army Night Vision \& Electronic Sensors Directorate (United States)

Derek Anderson, University of Missouri (United States)

10 Sensing Melange II

Sanjeev Agarwal, U.S. Army Night Vision \& Electronic Sensors

Directorate (United States)

Motoyuki Sato, Tohoku University (Japan) 


\section{Sensing Melange III}

Sanjeev Agarwal, U.S. Army Night Vision \& Electronic Sensors Directorate (United States)

Benjamin E. Barrowes, U.S. Army Engineer Research and Development Center (United States)

Proc. of SPIE Vol. $110121101201-11$

Downloaded From: https://www.spiedigitallibrary.org/conference-proceedings-of-spie on 26 Apr 2023 Terms of Use: https://www.spiedigitallibrary.org/terms-of-use 
Proc. of SPIE Vol. 11012 1101201-12

Downloaded From: https://www.spiedigitallibrary.org/conference-proceedings-of-spie on 26 Apr 2023 Terms of Use: https://www.spiedigitallibrary.org/terms-of-use 